\title{
South Asia's Economic Integration with East Asia: An Exploratory Analysis with a Focus on India
}

\author{
Venkatachalam Anbumozhi ${ }^{1+}$, Kaliappa Kalirajan ${ }^{2}$ \\ ${ }^{1}$ Economic Research Institute for ASEAN and East Asia, Indonesia \\ ${ }^{2}$ The Australian National University, Australia
}

\begin{abstract}
Economic integration of South Asia and East Asia has been growing steadily since the 1990s, fuelled by domestic reforms and the emergence of regional supply chains. Within South Asia, India emerged as the largest trading partner and investment destination for East Asian economies. With its new Act East Policy, India has been proactively looking at free trade agreements with Association of Southeast Asian Nation and East Asia, which has brought benefits to South Asia in terms of improved trade and increased investment. This paper assesses the experience of the economic integration of South Asia and East Asia by addressing questions such as the extent of trade integration achieved and impediments to deepening integration. It found that trade and investment linkages are growing as well as casually related. However, attaining the full potential of economic integration is constrained by the insufficient depth in the use of existing trade agreements, barriers to service trade, and poor infrastructure connectivity. Expansion of Regional Comprehensive Economic Cooperation would significantly enhance economic integration of South Asia, particularly India, and East Asia.
\end{abstract}

Keywords: Economic Integration, Infrastructure, Free Trade Agreements, Foreign Direct Investment, Regional Cooperation

\section{Introduction}

There has been a marked increase in regional economic cooperation between South Asia and East Asia since the 1990s. The initial push for greater economic integration and the establishment of improved economic ties between the regions can be attributed to the following factors: (1) economic reforms in China since the 1980s, (2) greater level of trade and investment openness in India beginning in the 1990s, (3) emergence of global value chains in Southeast Asia, (4) domestic policy reforms in other South Asian countries, and (5) expansion of East

\footnotetext{
+Corresponding Author: Venkatachalam Anbumozhi

Senior Economist, Economic Research Institute for ASEAN and East Asia, Sentral Senayan II, 6F, jalan Asia Africa No 8, GBK, Senayan, Jakarta, Indonesia, Tel: +628119106874, Email: v.anbumozhi@eria.org

Co-Author: Kaliappa Kalirajan

Professor, Crawford School of Public Policy, The Australian National University, Canberra, Australia, Tel: $+61-26125-8258$, Email: kaliappa.kalirajan@anu.edu.au
} 
Asian technology and service markets. As a result, bilateral trade and investment flows between the regions have increased. Drysdale and Armstrong (2010) argued that Asia has become a very important player in the 21 st century international arena with respect to its contribution toward strengthening global governance and international policy outcomes. They also noted that the nexus between regional cooperation and global coordination has not been sufficiently strong. One issue that they identified in this context is the missing links within Asia, particularly between South Asia and East Asia (Armstrong, Drysdale and Kalirajan 2008), which are, respectively, the emerging and sustained growth centers of the world. India is the largest economy in South Asia in terms of gross domestic product (GDP), arable land, and population. The GDP share of India in South Asia increased from 73 per cent in the early 1990s to over 80 per cent in the late 2010 s, mainly due to its relatively higher growth momentum among South Asian countries. India's average economic growth increased from 5.5 per cent in the 1980 s to 8.5 per cent during 1995 2000 and to nearly 9 per cent in the latter half of the 2000 2015 period. India become the founding member of the East Asia Summit in 2005, an Association of Southeast Asian Nation (ASEAN)-centric economic and security forum consisting of 18 Southeast and East Asian countries. Furthermore, in 2014, India adopted the Act East policy, signaling the adoption of a more proactive approach toward East Asia than they had in the past. The rest of South Asia lacks a formal perspective of East Asia, but some economies like Pakistan, Sri Lanka, and Nepal have sought closer economic ties with major East Asian economies like China and Japan. For instance, the China-Pakistan free trade agreement (FTA) was concluded in 2006 and went into effect in July 2007. FTA negotiations between Sri Lanka and China and between Bangladesh and Japan began in 2014.

Nevertheless, Dreze and Sen (2013) argued that South Asia's full trade growth potential has not been achieved and that there is an existing gap between India's potential performance and actual achievement. This stems mainly from the fact that it overlooked learning from the successful examples of East and Southeast Asian countries, despite the fact that in the early 1990s it initiated the "Look East Policy" to increase their engagement with the most world's most economically dynamic region. This paper assesses the experience of South and East Asia integration over the past three decades, with a focus on the following three research questions: (i) How much has South Asia's and East Asia's trade and foreign direct investment grown? (ii) What is the critical role of India's economy in the intra- and inter-regional economic integration? and (iii) What impedes further economic integration between South and Southeast Asia? The second section of the paper analyses the flow of trade, production network-related investments, and foreign capital. The third section discusses the major reforms undertaken by India and the potential for the further enhancement of trade integration between South Asia and East Asia. The fourth section explores the impediments to enhanced economic integration of South Asia and East Asia. The last section concludes. 


\section{Trade and Investment Flows between South Asia and East Asia}

\section{A. Traditional trade flows}

In the modern period, two distinct periods form the foundation of the economic ties between South Asia and East Asia. First, there was a period of limited economic cooperation that lasted from about 1945 until the late 1980s; and second, another period of intensifying effort for cooperation extended from the 1990s until the present (Menon and Srinivasan 2018). Before the 1990s, South and East Asian economies were relatively isolated from one another in terms of bilateral trade and investment flows of goods and services. The only FTA that covered the two sub-regions was the Asia-Pacific Trade Agreement (APTA). The relative isolation of these regions stemmed from a lack of policy signals, poor connectivity, and cultural and political barriers. Following their independence from British rule, most South Asian countries adopted import substitution industrialization strategies with high import tariffs and licensing to control the entry of outside industries and other farms state interventions to nurture their own domestic industries (Rana and Dowling 2009).

Table 1 summarizes the attributes of South Asian exports to East Asia during the second period. Between 1990 and 2015, exports to East Asia from South Asia grew rapidly at the rate of 13.2 per cent per year while imports from East Asia grew at the rate of 13.7 per cent. The total value of all trade between the two regions amounted to 235.2 billion US dollars in 2013. India made up nearly 75 per cent of South Asia's trade with East Asia, and witnessed double-digit growth during that period. Bangladesh, Pakistan and Sri Lanka also experienced growth in East Asia's import levels although their exports have for the most part lagged. Other countries in the South Asia region, such as Afghanistan, the Maldives, and Nepal, are at still in the early stages of establishing open trade with East Asia.

The share of South Asia's exports to East Asia increased from 14.5 to 17.9 per cent between 1990 and 2015, and its share of imports from 22.5 to 27.9 per cent. Underlying this major shift was a realignment of India's trade and investment policies toward East Asia, which accounted for one-fifth of exports and one-quarter of imports in 2015. Similarly, Pakistan also experienced a shift in trade with East Asia, specifically, with China and Japan. However, the rest of South Asia shows varying degrees of trade orientation toward East Asia. India's experience suggests that trading with East Asia offers South Asia a potentially dramatic enlargement of its economic horizons, making available a far greater regional market with which it can integrate economically (Kathuria, Kedia and Balakrishnan 2018).

An internal shift is also visible in terms of South Asia's trade with East Asia. The share of South Asia's exports to Japan fell from 57.8 per cent to 12.0 per cent between 1990 and 
2015. Meanwhile, its share of exports to China rose from 3.0 per cent to 26.6 per cent, to Singapore from 13.4 per cent to 20.4 per cent, to Indonesia from 3.8 per cent to 8.1 per cent, and to Vietnam from 0.5 per cent to 8.2 per cent.

Table 1. Growth in south asia-east asia trade, 1990 2015

\begin{tabular}{|c|c|c|c|c|}
\hline & \multirow{2}{*}{$\begin{array}{l}\text { Value in } 2015 \\
\text { million US dollars }\end{array}$} & \multirow{2}{*}{$\begin{array}{c}\text { Annual Average Growth } \\
1990 \sim 2015\end{array}$} & \multicolumn{2}{|c|}{ East Asia's share of Total $(\%)$} \\
\hline & & & 1990 & 2015 \\
\hline \multicolumn{5}{|l|}{ Exports } \\
\hline South Asia & 67,917 & 13.2 & 14.5 & 17.9 \\
\hline India & 60,477 & 14.7 & 14.6 & 19.4 \\
\hline Pakistan & 4,665 & 7 & 17.6 & 18.6 \\
\hline Bangladesh & 1,783 & 11.2 & 9.3 & 6.5 \\
\hline Sri Lanka & 843 & 6.8 & 9.9 & 8.7 \\
\hline Nepal & 60 & 6.6 & 6.6 & 7.6 \\
\hline The Maldives & 75 & 7 & 30.1 & 34.3 \\
\hline Afghanistan & 12 & 6.7 & 2 & 3 \\
\hline \multicolumn{5}{|l|}{ Imports } \\
\hline South Asia & 167,327 & 13.7 & 22.8 & 27.9 \\
\hline India & 116,697 & 16.1 & 15.8 & 25 \\
\hline Pakistan & 20,411 & 10.5 & 27.6 & 37.9 \\
\hline Bangladesh & 17,578 & 12 & 35.5 & 44.5 \\
\hline Sri Lanka & 8,514 & 10.1 & 35.2 & 39.8 \\
\hline Nepal & 2,720 & 10 & 51.5 & 39.1 \\
\hline The Maldives & 567 & 8 & 70.1 & 40.2 \\
\hline Afghanistan & 839 & 4.7 & 60.4 & 10.1 \\
\hline
\end{tabular}

(Source) These data are sourced by the authors, as compiled from the International Monetary Fund database (see http://data.imf.org).

The commodity composition of trade between South and East Asia economies tends to reflect national differences within South Asia in terms of each nation's comparative advantages with respect to natural resources, capital, labor, and technology, and levels of economic development. With an abundance of natural resources and labor, South Asia's exports to East Asia are weighted toward such products. Meanwhile, South Asia's imports from East Asia mainly consist of finished and high- technology goods, reflecting the abundance of capital and technology available in East Asia.

\section{B. Trade associated with regional supply chains and global production networks}

Traditional trade and FDI flows in East Asia have been progressively replaced by a new form of industrial trade centered on sophisticated global production networks and regional supply 
chains (Kimura and Kobayashi 2009). Therefore, production processes are fragmented into several slices that are located in different countries throughout South and East Asia in order to reduce production costs. Production fragmentation has spurred growing intra-regional trade in intermediate goods in Southeast and East Asia (Urata 2008). This spread of production networks, as well as the emergence of regional supply chains, spurred East Asia's global rise to the title of Factory Asia, which accompanied their rapid economic growth over a relatively long period. China, strikingly, has emerged as the largest trader in East Asia. Production networks have made Southeast Asia and China more prosperous since the early 1990s. However, there is little indication of the dispersion of production networks and supply chains into South Asia. Table 2 suggests that South Asian economics play a relatively small role in global production networks as compared to East Asian economics.

Table 2. Average share of world production network exports, 2001 2015

\begin{tabular}{lccc}
\hline & $2001 \sim 2005$ & $2006 \sim 2010$ & $2011 \sim 2015$ \\
\hline South Asia & $\mathbf{0 . 9 5}$ & $\mathbf{1 . 2 3}$ & $\mathbf{1 . 5 8}$ \\
India & 0.45 & 0.68 & 0.84 \\
Pakistan & 0.11 & 0.11 & 0.12 \\
Bangladesh & 0.26 & 0.33 & 0.49 \\
Sri Lanka & 0.12 & 0.11 & 0.12 \\
Nepal & 0.01 & 0 & 0 \\
The Maldives & 0.01 & 0 & 0 \\
Afghanistan & 0 & 0 & 0 \\
Bhutan & 0 & 0 & 0 \\
ASEAN & 9.61 & 9.29 & 9.34 \\
China & 12.54 & 19.2 & 24.99 \\
Japan & 11.12 & 9.61 & 7.9 \\
South Korea & 4.16 & 4.89 & 4.85 \\
\hline
\end{tabular}

(Source) UNCOMTRADE Database

Production network exports are defined as the trade in parts and components using the gross trade approach of Athukorala (2011). More specifically, it includes the total exports of SITC 75 79 and 87 88 as well as parts and components exports. The data in Table 2 demonstrate that between 2001 2005 and 2011 2015, South Asian countries' share of world production network exports increased from 0.95 per cent of global production network exports to 1.58 per cent. This trend has been fuelled by an increase in India's world share from 0.45 per cent to 0.84 per cent and Bangladesh from 0.26 per cent to 0.49 per cent. Meanwhile, the world shares of Pakistan and Sri Lanka have stagnated during this time period. The data also underline the important role of East Asia in global production networks. Thus, China makes up as much as 24.99 per cent of world production network exports. The 10 ASEAN economies as a group 
account for 9.34 per cent, Japan for 7.90 per cent, and South Korea for 4.85 per cent.

\section{FDI flows between South Asia and East Asia}

The data on private capital flows are more limited than are trade data. Data on greenfield investment suggest that FDI flows between South and East Asia have nearly doubled, from 5.0 billion US dollars in 2003 to 8.2 billion US dollars to 2013, but from a low base. The FDI flow from less-developed South Asia to more developed East Asia is lower than the flow in the other direction. As shown in Table 3, annual flows of FDI from South Asia to East Asia were only about 4 billion US dollars during the 2003 15 period. However, FDI flows from East Asia to South Asia more than doubled at over 10 billion US dollars.

Table 3. Foreign direct investment flows to and from south asia

\begin{tabular}{|c|c|c|c|c|c|c|}
\hline & \multicolumn{3}{|c|}{ East Asia to South Asia } & \multicolumn{3}{|c|}{ South Asia to East Asia } \\
\hline & $\begin{array}{c}\text { Annualized } \\
\text { Average } \\
2003 \sim 2015 \\
\text { (million US dollars) }\end{array}$ & $\begin{array}{l}\text { Cumulative } \\
2003 \sim 2015 \\
\text { (million US } \\
\text { dollars) }\end{array}$ & $\begin{array}{c}\text { Share } \\
(\%)\end{array}$ & $\begin{array}{c}\text { Annualized } \\
\text { Average } \\
2003 \sim 2015 \\
\text { (US million dollars) }\end{array}$ & $\begin{array}{c}\text { Cumulative } \\
2003 \sim 2015 \\
\text { (million US } \\
\text { dollars) }\end{array}$ & $\begin{array}{c}\text { Share } \\
(\%)\end{array}$ \\
\hline South Asia & 10,248 & 112,731 & 100 & 4,047 & 44,522 & 100 \\
\hline India & 8,602 & 94,621 & 84 & 4,014 & 44,157 & 99 \\
\hline Pakistan & 796 & 8,760 & 8 & 15 & 165 & 0 \\
\hline Bangladesh & 123 & 1,352 & 1 & 9 & 94 & 0 \\
\hline Sri Lanka & 233 & 2,568 & 2 & 6 & 70 & 0 \\
\hline Maldives & 132 & 1,452 & 1 & NA & NA & NA \\
\hline Nepal & 23 & 258 & 0 & 3 & 37 & 0 \\
\hline Afghanistan & 311 & 3,421 & 3 & NA & NA & NA \\
\hline
\end{tabular}

(Source) http://www.fdimarkets.com.

Cumulative FDI flows from East Asia to South Asia over the 2003 2015 period were 112.7 US billion dollars. In contrast to trade flows, Japan, accounting for 36.9 per cent of the cumulative FDI flows in the 2003 2015 period, is the leading foreign investor in South Asia followed by Korea (19.7 per cent) and China (18.5 per cent). Singapore (11.6 per cent) and Malaysia (10.3 per cent) follow some way behind. Nataraja (2010) argues that Japanese inward investment in India is below its potential due to constraints in the investment climate, such as poor infrastructure, strict labor laws, and complex business procedures.

Like trade, India dominates regional FDI flows, accounting for 99.2 per cent of cumulative FDI flows from South Asia to East Asia and 83.9 per cent of cumulative FDI flows from East Asia to South Asia between 2003 and 2015. Other South Asian economies have made smaller investments in East Asia but have received some East Asian FDI. Pakistan notably accounts for 7.8 per cent of cumulative FDI flows from East Asia to South Asia. 
Capital inflows from East Asia to India during the period between 2003 and 2015 are diversified. The largest FDI activity is in automotive and parts at 22.2 per cent. This is followed by: metals at 18.2 per cent, real estate at 6.2 per cent, communications at 4.0 per cent, consumer electronics at 4.0 per cent, engines and turbines at 4.0 per cent, industrial machinery equipment and tools at 3.9 per cent, and semiconductors at 3.9 per cent. Meanwhile India's outflows of FDI to East Asia are concentrated in resource activities, 34.0 per cent in metals and 14.1 per cent in coal oil, and gas and service activities, 10.3 per cent in financial services, 8.5 per cent in software and information technology (IT) services, 2.2 per cent in transportation, and 2.2 per cent in hotels and tourism.

The leading investor in East Asia is Japan with 35 per cent of cumulative FDI into India between 2003 and 2015; nearly half of this was channeled into automotive products and parts. Japanese FDI was also directed into machinery and tools, electronics, chemicals, and rubber. South Korea, in second place, accounted for 19 per cent of cumulative FDI into India; one-third of Korean FDI went into metals and another one-fifth into automotive products and parts. China is the third largest investor into India with 13 per cent of its cumulative FDI; just under half was put in metals and another one-fifth into engines and turbines. Singapore is fourth with 11 per cent of cumulative FDI, one-third of which was directed into real estate and another quarter into semiconductors.

\section{Mapping India's Economic Performance and the Potential of Economic Integration with East Asia}

\section{A. Reforms to promote economic growth and alignment with East Asian economies}

Because many South, Southeast, and East Asian governments are keen to see India play a more active economic role in the region, it is imperative to examine the status of India in East Asian integration. Since its independence in 1947, although several policy regimes that constrained India's integration with regional and global markets existed, the most crucial were its trade and investment policies. Until 1991, India adopted import substitution and overvalued exchange rate policy regimes, as well as other forms of state intervention into its economy. This policy regime was supported by other policy measures, such as industrial licensing and price controls, which restricted FDI. Consequently, India developed a high-cost domestic industrial structure that was out of alignment with world prices (Sankar 2001). Influenced by India's then prevailing economic philosophy of anti-globalization, smaller South Asian economies also developed similar industrial development strategies to varying degrees. Growth and trade in 
a provincial and inward-oriented India thus largely stagnated. Meanwhile, after an initial import substitution period, East Asian economies, initially South Korea, Taipei, China, and then ASEAN, switched to outward-oriented industrial development strategies in the 1960s. New emphasis was given to priorities such as the liberalizing trade policy, attracting export-oriented FDI via export processing zones, and using market mechanisms for resource allocation (World Bank 1993).

In India, this occurred during the 1990s in the form of economic reforms that sought to eliminate inherently growth-impeding exchange rate, trade, and investment policies by modifying industrial policy, removing many price and distribution controls, and by restructuring the fiscal, financial, and public sectors to a considerable extent (Acharya 2010). Figure 1 shows average unweighted nominal tariff rates across South Asia, including India, as compared with the world. A drastic reduction in South Asian tariff rates over these years can be noted, although rates are still higher than the worldwide average. India's applied average tariff rate for manufactured products decreased from 83 per cent in 1990 to 10 per cent in 2009, with the aim of encouraging investment in domestic industries in order to improve production technologies and promote growth in exports.

Figure 1. Average unweighted nominal tariff rates: south asia and the world.

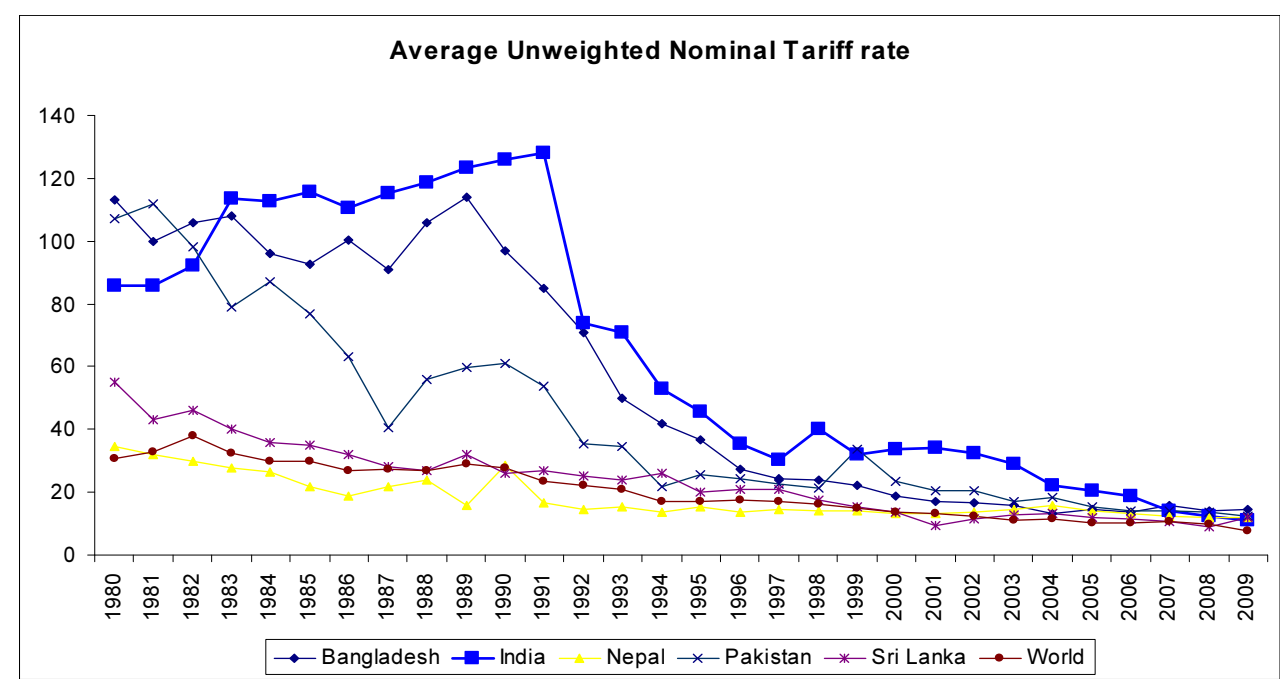

(Source) World Trade Organization (WTO), International Trade Commission, and United Nations Conference on Trade and Development (various years).

During this period, the Indian IT industry gained the reputation of being a significant and progressive world leader. The availability of world class technical personnel, a proficiency in English, cost competitiveness, quality research and training institutes, and effective reform measures has transformed India into a sought-after destination to which companies around the 
world could outsource their IT business. Direct employment generation reached nearly 2.8 million in 2015, while indirect job creation rose to \$8.9 million (Eichengreen and Gupta 2011). India initiated another policy reform to strengthen its globalization process with respect to FDI, which brought with it updated technology and a larger number of markets for exports. Compared to the pre-reform years, the new FDI policy now allows 100 per cent foreign ownership in many industries and a majority ownership in all sectors with the exception of banks, insurance companies, telecommunications, and airlines.

As a way of guaranteeing the benefits to small- and medium-sized businesses the government has imposed two significant compulsory conditions on foreign retailers. First, they must source at least one-third of the products they sell from small- and medium-sized enterprises whose total investments do not exceed \$1 million. Second, they must invest at least $\$ 100$ million, half of which must be channeled into back-end infrastructure over a three-year period (Kalirajan Singh and Drysdale 2010). FDI approval procedures were simplified with the provision of a list of industries that enjoy automatic approval up to specified levels of foreign equity (i.e., 100 per cent, 74 per cent, and 51 per cent) and the foreign investors in these industries with specified equity levels need only register with the Reserve Bank of India (RBI) for approval.

In order to strengthen India's trade and investment links with the rest of the world, India embarked on initiating the formation of a regional group, besides negotiating and signing FTAs and comprehensive economic cooperation agreements or comprehensive economic partnership agreements with East Asian countries. India has signed 17 different types of regional trading and economic partnership agreements that are currently operational. As shown in Figure 2, the implementation of the ASEAN-India FTA has facilitated an increase in intra-regional trade and investment liberalization (ADBI 2015).

Figure 2. Increase in trade between India and ASEAN-member countries.

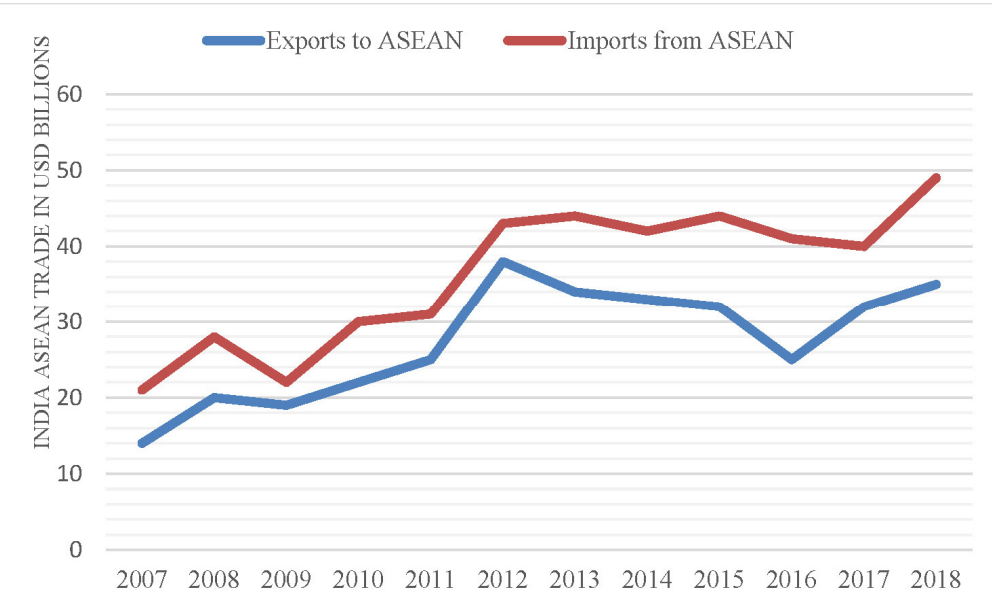

(Source) Department of Commerce, Government of India. 
India's biggest trade partner in the Southeast and East Asia regions is China, with which it has huge deficits and higher value exports than imports. Table 4 illustrates total trade volume in 2015. The Philippines, Lao PDR, Myanmar, and Cambodia are the only countries with which India has a trade surplus, but the trade volume between these countries is less. This trade deficit has also become a contentious issue in negotiations over pan-Asian mega-trade agreements like the RCEP.

Table 4. India's trade balance (in million) with southeast and east asian countries

\begin{tabular}{ccccc}
\hline Country & Imports & Exports & Total Trade & Deficit \\
\hline China & 70.32 & 16.75 & 87.07 & -53.57 \\
\hline Singapore & 16.28 & 11.57 & 27.85 & -4.71 \\
\hline South Korea & 16.76 & 4.71 & 21.46 & -12.05 \\
\hline Indonesia & 15.84 & 5.28 & 21.12 & -10.57 \\
\hline Japan & 12.77 & 4.86 & 17.63 & -7.91 \\
Malaysia & 10.82 & 6.44 & 17.25 & -4.38 \\
Australia & 13.13 & 3.52 & 16.65 & -9.61 \\
\hline Vietnam & 7.19 & 6.51 & 13.7 & -0.68 \\
Thailand & 7.44 & 4.44 & 11.88 & -3 \\
\hline Philippines & 0.58 & 1.74 & 2.32 & 1.16 \\
\hline
\end{tabular}

(Source) Department of Commerce, Government of India.

\section{B. Commodity composition of India's trade with East Asia}

While stagnation in manufacturing in India has attracted considerable research attention, India's commodity composition of trade reflects India's comparative advantage in natural resources, capital, and labor. To illustrate this pattern of trade, the leading items in India's trade with East Asia since 1991 are listed in Table 5.

India's main exports to East Asia include natural resource-intensive products like mineral fuels, pearls, stones, iron ore, colon fish, non-ferrous metals and ores, granite, leather, oil cake, as well as some skill- and technology-intensive goods such as chemicals, plastics, ships, and machinery. In contrast, East Asia's leading exports to South Asia feature products such as computers and integrated circuits, televisions, radios, telecommunication equipment, motor vehicles and motor vehicle parts, and chemicals and fuels. Where there is a two-way trade in the same industry, East Asian exports tend to feature a higher level of processing. For the steel industry, India's leading exports to East Asia include ferro-alloys, pig iron, and rolled steel. East Asia's leading exports to South Asia include rolled steel of a heavier grade. 
Table 5. India's top 10 commodities traded with east asia

\begin{tabular}{|c|c|c|c|}
\hline $\begin{array}{c}\text { Commodity } \\
\text { Code }\end{array}$ & Commodity Description & 2000 & 2015 \\
\hline \multicolumn{4}{|c|}{ Share of Total Exports } \\
\hline 27 & Mineral fuels, mineral oils, and products of their distillation & 0 & 8.1 \\
\hline 71 & Natural or cultural pearls, precious or semi-precious stones, precious metals & 17.5 & 6.8 \\
\hline 52 & Cotton & 4.6 & 2.5 \\
\hline 29 & Organic chemicals & 1 & 2.1 \\
\hline 26 & Ores, slag, and ash & 8 & 1.7 \\
\hline 89 & Ships, boats, and floating structures & 0 & 1.3 \\
\hline 74 & Copper and articles thereof & 0.1 & 1.2 \\
\hline 84 & Nuclear reactors, boilers, machinery and mechanical appliances, and parts thereof & 0.1 & 1.2 \\
\hline 72 & Iron and steel & 0.1 & 1 \\
\hline 10 & Cereals & 0.1 & 1 \\
\hline \multicolumn{4}{|c|}{ Share of Total Imports } \\
\hline 85 & Electrical machinery and equipment, and parts thereof & 10.6 & 15.8 \\
\hline 84 & Nuclear reactors, boilers, machinery and mechanical appliance, and parts thereof & 13.4 & 15 \\
\hline 27 & Mineral fuels, mineral oils, and products of their distillation & 5.7 & 9.5 \\
\hline 71 & Natural or cultural pearls, precious or semi-precious stones, and precious metals & 0.5 & 6.8 \\
\hline 29 & Organic chemicals & 3.9 & 6.3 \\
\hline 15 & Animals or vegetable fats and oils & 4.5 & 6.2 \\
\hline 72 & Iron and steel & 6.8 & 4.1 \\
\hline 39 & Plastics and articles thereof & 3.7 & 3.1 \\
\hline 89 & Ships, boats, and floating structures & 2.7 & 3 \\
\hline 87 & Vehicles other than railway or tramway rolling stock & 2.2 & 6.4 \\
\hline
\end{tabular}

(Source) Compiled by the authors from the United Nations Comrade database (see http://comtrade.un.org).

\section{Impediments to South Asia-East Asia Economic Integration}

While the pace of South Asia-East Asia economic integration has picked up since 1990, many impediments at the national and regional levels remain, which can hamper further trade and investment flows. Four key impediments to economic integration are: (i) trade barriers and cumbersome business procedures; (ii) barriers to services trade; (iii) risk of insufficient depth and business use of FTAs; and (iv) gaps in infrastructure.

\section{A. Trade barriers and complex business procedures}

Market-friendly policy regimes are critical for promoting South Asia-East Asia economic integration. Lower trade barriers and streamlined business procedures lower trade costs and 
facilitate the spread of production networks (Kearney 2012). Although tariff protection has been falling in South Asia, overall their tariffs are typically higher than those in East Asia. Table 6 shows import tariffs for agricultural companies and manufacturers along with Non-Tariff Measures (NTMs) implemented during the 2009-15 period and the World Bank's Ease of Doing Business indices.

Table 6. Non-tariff barriers and ease of doing business rankings for south asian and east asian countries

\begin{tabular}{|c|c|c|c|c|c|c|}
\hline & \multicolumn{2}{|c|}{$\begin{array}{l}\text { Simple Average } \\
\text { MFN Tariffs for } \\
\text { Agriculture }\end{array}$} & \multicolumn{2}{|c|}{$\begin{array}{l}\text { Simple Average } \\
\text { MFN Tariffs for } \\
\text { Manufacturers }\end{array}$} & \multirow{2}{*}{$\begin{array}{c}\text { NTMs } \\
\text { Implemented } \\
2010 \sim 2015\end{array}$} & \multirow{2}{*}{$\begin{array}{c}\text { Ease of Doing } \\
\text { Business Rank } \\
\text { (out of } 189 \\
\text { economies) } \\
2015\end{array}$} \\
\hline & 1990 & 2015 & 1990 & 2015 & & \\
\hline India & 77.0 & 33.5 & 84.1 & 10.2 & 206 & 134 \\
\hline Pakistan & 45.5 & 15.4 & NA & 13.2 & 16 & 110 \\
\hline Bangladesh & 99.5 & 16.8 & 123.1 & 13.4 & 1 & 130 \\
\hline Sri Lanka & 98.1 & 25.7 & 27.0 & 7.5 & 10 & 85 \\
\hline The Maldives & 18.2 & 18.3 & NA & 20.8 & 1 & 95 \\
\hline Nepal & 9.4 & 13.8 & 18.9 & 120.0 & 2 & 105 \\
\hline Afghanistan & NA & 7.1 & NA & 5.7 & 1 & 164 \\
\hline Bhutan & 14.3 & 41.4 & 15.5 & 18.9 & 0 & 141 \\
\hline China & 42.5 & 15.6 & 43.9 & 9.0 & 98 & 96 \\
\hline Indonesia & 20.1 & 7.5 & 19.3 & 6.7 & 68 & 120 \\
\hline Korea & 11.4 & 52.7 & 7.8 & 6.8 & 19 & 7 \\
\hline Malaysia & 12.7 & 8.9 & 9.4 & 5.5 & 9 & 6 \\
\hline Thailand & 40.5 & 29.9 & 41.7 & 8.3 & 11 & 18 \\
\hline Philippines & 23.1 & 9.9 & 20.9 & 5.7 & 5 & 108 \\
\hline Vietnam & 17.7 & 16.2 & 14.3 & 8.3 & 21 & 99 \\
\hline
\end{tabular}

(Source) Compiled by authors from World Bank database, Global Trade alert database, and the ERIA NTM database.

The average agricultural tariff in India is 33.5 per cent, while in China it is 15.6 per cent. Interestingly, in 2015, average manufacturing tariffs for China and India were similar, at 9.0 per cent and 10.2 per cent, respectively, with India showing a large reduction between 1990 and 2015. Furthermore, while tariffs are seen as low in many East Asian countries, NTMs can be reduced. The number of NTMs implemented in 2015 was 98 for China, 68 for Indonesia, and 19 for South Korea. These figures compare with 206 for India, 16 for Pakistan, and 10 for Sri Lanka.

According to World Bank Ease of Doing Business indicators, East Asia is typically a more open destination than South Asia. As the earliest adopter of economic reform in South Asia, Sri Lanka has the highest rank, 85th within the sub-region followed by the Maldives, at the rank of 95th. However, large South Asian economies achieve rankings well in excess of 100 . 
Meanwhile, Malaysia is ranked 6th, South Korea 7th, and Thailand 18th, Hence, East Asia also benefits more from a potential regional integration of industries through a dense network of global production networks and supply chains, as well as large domestic markets.

Efforts at trade liberalization and streamlining business procedure in South Asia need to be embedded in a wider program of next generation of economic reforms. Important measures would include fiscal consolidation, reform of state-owned enterprises, improvement of domestic competition policy, reforms to the civil service and delivery of public goods, and reforms to institutions that create human capital such as technical education and health insurance (Pant 2012).

\section{B. Services trade barriers}

Several studies (ERIA 2014, Kumar et al. 2008, ADB 2008) suggest that services have been on the rise in output in South Asia and East Asia. From 45 per cent of the average share in 1990, the service sector made up 48.5 per cent of GDP in 2010. In the newly industrialized economics of East Asia such as South Korea; Hong Kong; China; and Taipei the services sector has GDP shares of 60-90 per cent. In the ASEAN economies, the sector makes up less than 50 per cent of GDP. South Asian economies have uniformly growing services sectors, particularly India, Sri Lanka, and Nepal where shares have risen annually by 15 to 20 per cent.

The service sector is also an important contributor to enhanced trade between South and East Asia. The average share of services trade in GDP in South Asian economies was 13 per cent in 2015 compared with 25 per cent in East Asia. India and Sri Lanka are outliers in South Asia, with shares of 15 per cent and 11 per cent respectively. Pakistan, Bangladesh and Nepal have quite low shares. East Asia has an even greater diversity in services trade between high and low shares: Singapore 92 per cent, Thailand 27 per cent, Malaysia 26 per cent, Indonesia 6 per cent, and China 6 per cent.

There is significant potential for services trade between South Asia and East Asia. India's IT services exports grew to 14.5 per cent over the $2011-15$ period and was valued at $\$ 51.8$ billion (Reserve Bank of India 2017). There is considerable potential for further expansion since top Indian IT firms are currently attempting to diversify their marketing using various strategies, such as setting up offices in China, Korea, and Japan to serve those local markets. They are also trying to attract Japanese outsourcing business by employing workers from these countries in order to overcome the language barrier.

Contractual construction and labor services are China's major service sectors (Dee 2012). In South Asia, Pakistan is one of the most important markets for contractual construction and labor exports from China. China also has a history of construction and labor exports to Sri 
Lanka and Bangladesh. Meanwhile, South Asian and ASEAN countries export labor services; remittances from these economies are also increasing. Japan and South Korea provide selective opportunities for labor migration of high-skilled workers as their workforce age decreases. Healthcare, construction, agriculture, and parts assembly are some sectors in which South Asia enjoys demographic dividends.

However, there is evidence that important impediments to trade and investment-inhibiting trade in services exists between South Asia and East Asia. Table 7 provides a list of services trade restrictiveness indices for various South and East Asian countries.

Table 7. Services trade restrictiveness index

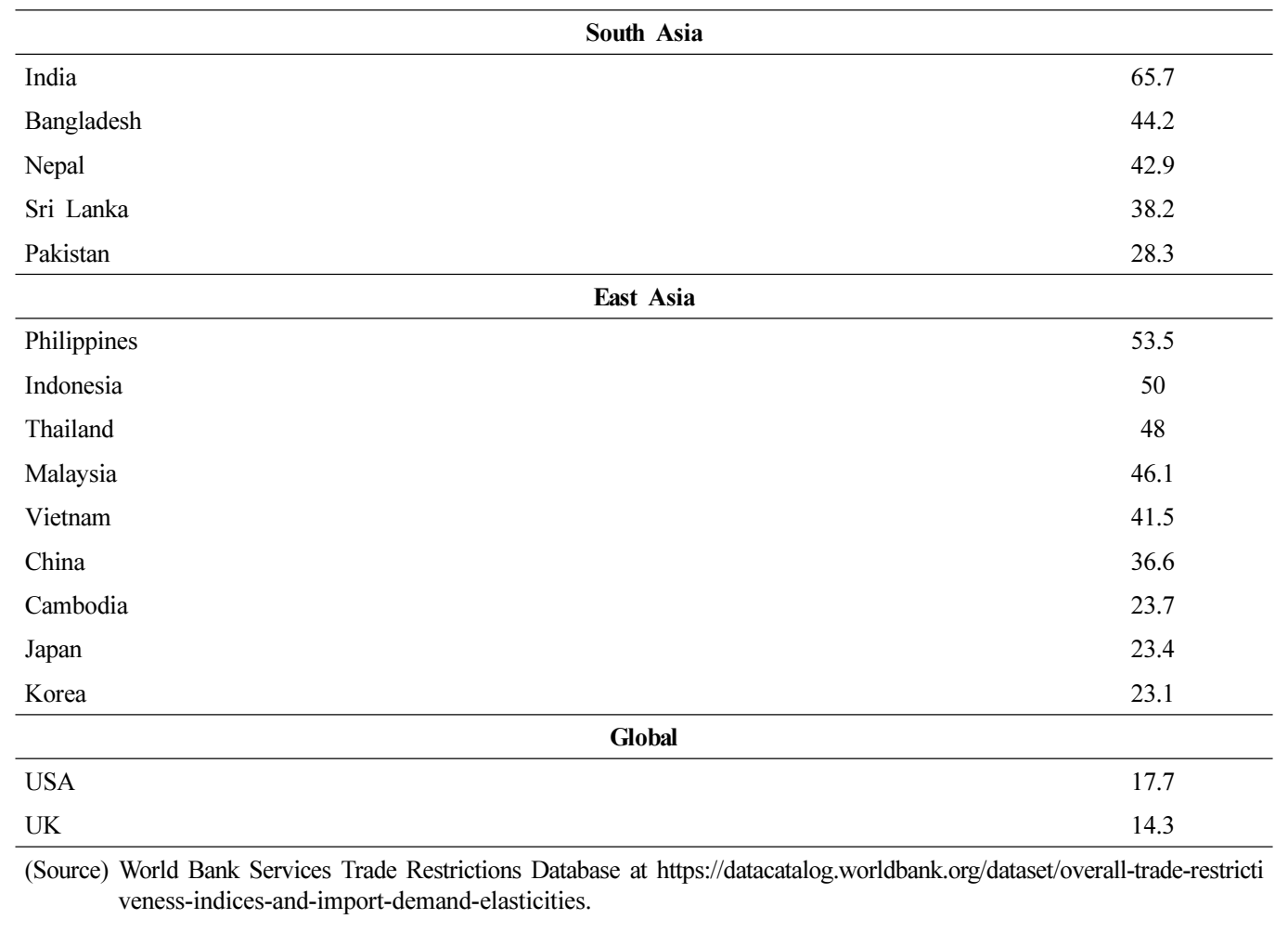

This data capture the policies and regulations that discriminate against foreign services as well as certain key aspects of the overall regulatory environment that have a notable impact on trade in services. A higher score suggests greater restrictiveness. The indices suggest that India has greater restrictions on trade in services than do major East Asian economies such as China, Japan, and South Korea. Trade in services restrictions in the South Asian countries of Bangladesh, Nepal, and Sri Lanka are slightly lower than levels in the Southeast Asian countries of the Philippines, Indonesia, Thailand, and Malaysia. There are concerns, particularly in South Asia, about the high cost of adjustment to the liberalization of the services trade 
on unemployment, poverty, and the loss of universal access to basic services (Noland, Park and Estrada 2013). Some South Asian countries have thus adopted a cautious approach to services trade liberalization.

Enhancing services trade between South and East Asia will be a challenging process (Kelegama 2009). First, a major cooperative effort at both the national and regional level is required, especially in South Asia, to improve data on the services sector and services trade. Second, it will involve creating competitive services markets through a combination of policy reform, productivity improvement, and investment in infrastructure and human capital.

\section{Types and insufficient business use of FTAs}

Preferential liberalization is a relatively recent phenomenon in South Asia-East Asia economic integration (Kalirajan et al. 2012). By December 2019, nine FTAs were in effect between South and East Asian countries, with eight of these in effect since 2004. More FTAs are currently being negotiated. Furthermore, these FTAs have only involved two of the largest economies in South Asia, namely, India and Pakistan. While it is early days in terms of South Asia-East Asia FTAs, two concerns have arisen.

First, agreements, in effect, vary in their provision of reductions in trade barriers. South Asia-East Asia FTAs fall into two types: (i) limited agreements that deal mainly with barriers to foods trade, and (ii) agreements that extend the liberalization beyond goods trade to tackle services and regulatory barriers. The APTA, the China-Pakistan FTA, and the Pakistan-Malaysia FTA are mainly goods agreements. The remaining FTAs are somewhat more comprehensive. The ASEAN-India FTAs initially covered goods liberalization but have recently expanded to cover services and investment. The India-Singapore FTA excludes agriculture and transit but features reasonable coverage of services and cooperation enhancement provisions. The India-South Korea FTA includes reasonable coverage of services and moderate coverage of regulatory barriers, while the India-Japan FTA covers some services and has wider coverage of regulatory barriers. In general, there seems to be room for improvement in the coverage of services and regulatory issues in South Asia-East Asia FTAs.

Second, use of tariff preferences in South Asia-East Asia FTAs differs between agreements. Analysis on export value using FTA preferences from national sources in Thailand, Malaysia, and Vietnam for a few FTAs revealed the usage rates. The Thailand data obtained from the Ministry of Commerce show an increase in the combined utilization rate of the Thailand-India FTA and the ASEAN -India FTA from 17.6 to 36.6 per cent between 2005 and 2011. The Vietnam data obtained from the ministry of industry and trade of Vietnam also indicate an increase in utilization of the ASEAN-India FTA between 2010 and 2011. However, the Malaysian data gathered from the Ministry of International Trade and Industry of Malaysia 
indicates a significant increase in utilization of the Pakistan-Malaysia FTA from 1.4 per cent to 74.3 per cent between 2006 and 2015 .

Thus, the evolving trend is toward insufficient liberalization and agreement depth, as well as sub-optimal preference use. Asia should pursue a geographically broad scheme, instead of an expanding web of bilateral and sub-regional agreements. Against the slow progress in WTO-led trade talks, a pan-Asian FTA, such as the Regional Economic Comprehensive Partnership (RECP), can promote continuing liberalization, induce structural reforms, and widen market access across the region. With the goal of making the proliferation of FTAs between South Asia and East Asia the stepping stones rather than stumbling blocks to multilateralism and reducing inefficiencies due to overlapping rules of origin, policymakers might consider adopting the concept of open regionalism and broaden FTAs by creating as large and wide a market as possible.

In this vein, one major pan-Asian FTA under negotiation is noteworthy. In November 2012, ASEAN members and their FTA partners agreed to negotiate an RCEP that would result in the world's largest trading bloc, covering 40 per cent of all world trade. The first round of RCEP negotiations took place in the middle of 2013 with the ambitious goal of being complete by 2015 . But that initial deadline passed and the RECP talks are not likely to conclude until 2020. India is the only South Asian economy to join the negotiations thus far. This will give Indian industries a greater opportunity to access East Asian markets, integrate themselves into regional production networks, and invest in East Asian IT services sectors. It will also expose domestic Indian businesses to competition and facilitate the upgrading of their skills and technology. None of the other South Asian economies has expressed a desire to join the RCEP, but this may change if they become concerned about being left out of such a large regional economic integration group.

\section{Infrastructure gaps}

Asia's trade performance and its ability to attract FDI depend fundamentally on efficient, reliable, and seamless infrastructure (ADB and ADBI 2009). The spread of global supply chains and production networks in East Asia means that manufacturing activities have been dispersed over geographical spaces connected by trade in parts, components, and services. India has gradually been incorporated into supply chains through FDI from Japan, South Korea, and ASEAN economies. Investment in cross-border infrastructure, multi-modal transport systems, and logistics is critical to facilitating South Asia and East Asia supply chain integration.

Detailed technical studies of infrastructure connectivity assess different transport options to efficiently and seamlessly integrate South Asia and East Asia into trade (Arnold 2009, ADB and ADBI 2015). These studies have also identified several missing links and bottlenecks, 
particularly maritime and land connectivity between South and East Asia. They found that the dominant mode for freight transport between the South and the East remains ocean transport and this is expected to continue into the foreseeable future. International shipping lines serving the South Asia-East Asia region operate on the equatorial route connecting East Asia with the Mediterranean. The introduction of larger container ships and the expansion of feeder services have supported trade growth. However, problems have been identified in the facilities and the operational efficiency of public ports and in the links between ports and road networks.

Furthermore, it is suggested that the recent opening up of Myanmar by means of economic reform indicates that land transport will have an increasing role in bilateral trade within the ASEAN, but major improvements are needed. New land corridors between India and China through Bhutan and Nepal are required, necessitating large investment. For instance, a minimum investment of $\$ 18$ billion is needed for road creation and improvement, specifically, to build 26,000 kilometers of road to complete the Asian highway project (ADB and ADBI 2009).

Inter-country comparisons of infrastructure quality provide an evaluation of ports, roads, railways, and air transport connectivity that might facilitate inter-regional trade. The data available in Table 8 suggest that the quality of infrastructure in South Asian economies typically lags behind that of East Asian economies.

Table 8. Quality of infrastructure in south asia in comparison with southeast and east asia

\begin{tabular}{lcccccc}
\hline & $\begin{array}{c}\text { Quality of Overall } \\
\text { Infrastructure }\end{array}$ & Roads & Railroads & Ports & Air Transport & $\begin{array}{c}\text { Electricity } \\
\text { Supply }\end{array}$ \\
\hline India & 3.9 & 3.6 & 4.8 & 4.2 & 4.8 & 3.2 \\
Pakistan & 3.3 & 4.0 & 2.5 & 4.5 & 3.2 & 2.0 \\
Bangladesh & 2.8 & 2.8 & 2.4 & 3.5 & 3.2 & 2.2 \\
Sri Lanka & 4.8 & 4.7 & 3.6 & 4.2 & 4.8 & 5.0 \\
Nepal & 2.9 & 2.7 & 1.1 & 2.7 & 3.0 & 1.6 \\
Bhutan & 4.9 & 4.3 & NA & 2.2 & 3.5 & 5.9 \\
China & 4.3 & 4.5 & 4.7 & 4.5 & 4.5 & 5.7 \\
Korea & 5.6 & 5.8 & 5.7 & 5.5 & 5.8 & 4.3 \\
Indonesia & 4.0 & 3.7 & 3.5 & 3.9 & 4.5 & 5.2 \\
Thailand & 4.5 & 4.9 & 2.6 & 4.5 & 5.5 & 5.2 \\
Malaysia & 5.5 & 5.4 & 4.8 & 5.4 & 5.8 & 5.8 \\
Philippines & 3.7 & 3.6 & 2.1 & 3.4 & 3.5 & 4.0 \\
Vietnam & 3.4 & 3.1 & 3.0 & 3.7 & 4.0 & 4.0 \\
\hline
\end{tabular}

(Source) World Economic Forum (WEF) 2013.

In terms of the quality of overall infrastructure, South Asia's largest economies fare poorly. India has a value of 3.9; Pakistan of 3.3, and Bangladesh of 2.8; Sri Lanka at 4.8 and Bhutan at 4.9 are the exceptions in South Asia. By comparison, South Korea has a value of 5.6, Malaysia 
of 5.5, and China of 4. Interestingly, the Philippines and Vietnam underperform in Southeast Asia. Thus, while improvements have occurred in regional infrastructure, South Asia, in particular, has a large unfinished agenda of improving the quantity and quality of its infrastructure.

\section{Conclusion}

This paper assesses the experience of South and East Asia economic integration by examining the growth of regional trade and investment patterns. Three important points emerge from this research. First, there is evidence of increased economic integration between South Asia and East Asia, but the process is uneven. Traditional bilateral trade flows have grown rapidly since 1990 from a small base led by India and to a lesser extent, Pakistan. South Asia is largely absent from the production network trade that has characterized East Asia's recent rise as the global factory. FDI flows, particularly from East Asia to South Asia, have increased but levels are smaller than regional trade levels. Additionally, the bulk of East Asian FDI goes to India. Little regional policy integration has occurred, with only a few recent South Asia-East Asia FTAs focusing on India and Pakistan. Smaller South Asian countries are in the early stages of integration, with East Asia imports from East Asia having grown, but exports network trade, FDI, and FTAs have lagged.

Second, India's Act East policy is a comprehensive and proactive measure toward achieving economic integration between South Asia and East Asia. There is a significant potential for India's IT services and young population, as well as their vibrant industries, to further enhance trade and investment between the regions. Effective utilization and expansion of regional trade agreements, such as RCEP, will significantly enhance economic integration between South Asia and East Asia. Third, there are a myriad of problems in the way of further economic integration. These include trade barriers affecting businesses, barriers to services trade, a risk of insufficient use of FTAs, and infrastructure gaps. The analysis suggests that these problems are particularly challenging in South Asian and in some Southeast Asian economies. Thus, South Asia-East Asia economic integration represents a work in progress. A large and coordinated effort is needed at the national and sub-regional levels, particularly in South Asia, to ensure its future success. India may be well positioned to play such a coordinating role under their Act East policy.

\section{References}

Acharya, S. (2010). "Macroeconomic Performance and Policies, 2000-08." in India's Economy: Performance and Challenges: Essays in Honour of Montek Singh Ahluwalia, eds. S. N. Acharya and R. Mohan. 
New Delhi: Oxford University Press.

ADB (2008). Emerging Asian Regionalism: A Partnership for Shared Prosperity, Asian Development Bank, Manila.

ADB and ADBI (2009). Infrastructure for a Seamless Asia. Manila and Tokyo, Asian Development Bank and Asian development Bank Institute.

ADBI (2015). Connecting South Asia and Southeast Asia, A joint study by the Asian Development Bank and the Asian Development Bank Institute, ADBI, Tokyo.

Armstrong, S., Drysdale, P., and Kalirajan, K. (2008). "Trade structures and trade potential: An initial analysis of South and East Asian Trade." Available at SSRN: http://ssrn.com/abstract=1767686

Athukorala, P. (2011). "Production networks and trade patterns in East Asia: Regionalization or globalization." Asian Economic Papers, 10, no. 1, 65-69.

Dee, P. (eds.) (2012). Economic reform process in South Asia: Toward policy efficiency, Abingdon, UK: Routledge.

Dreze, J., and A. Sen (2013). An uncertain glory: India and its contradictions, Princeton: Princeton University Press.

Drysdale, P., and S. Armstrong (2010). "International and regional cooperation: Asia's role and responsibilities." EABER Working Papers 22763, East Asian Bureau of Economic Research, The Australian National University.

Eichengreen, B., and P. Gupta (2011). "The Service Sector: India's Road to Economic Growth?.” in India Policy Forum 2010/11, eds. S. Bery, B. Bosworth and A. Panagariya. New Delhi: Sage Publications.

ERIA (2014). ASEAN rising: ASEAN and AEC beyond 2015, Economic Research Institute for ASEAN and East Asia, Jakarta.

Kalirajan, K., K. Singh, and P. Drysdale (2010). "Impact of big shopping malls and retailers on employment and consumer prices in India." Journal of International Economics 1, no. 2, 62-75.

Kalirajan, K., R. Prasad, and P. Drysdale (2012). "Have China \& India achieved their potential in attracting Foreign Direct Investment?.” Journal of Emerging Knowledge on Emerging Markets 4, no. 1, 117-127.

Kathuria, R., M. Kedia, and U. Balakrishnan (2008). "Mapping the Future of High Value Manufacturing in India." in Integrating South and East Asia, eds. Menon J and T N Srinivasan. Oxford University Press. New Delhi, 202-248.

Kearney, A. T. (2012). Cautious Investors Feed a Tentative Recovery, The 2012 AT Kearney Foreign Direct Investment Confidence Index, New York: AT Kearney.

Kelegama, S. (2009). "Introduction: Opportunities and Risks in Liberalizing Trade in Services." in Trade in Services in South Asia: Opportunities of Liberalization (pp. 1-22). ed. S Kelegama. New Delhi: Sage Publication.

Kimura, F., and Kobayashi, I. (2009). "Why is the East Asia Industrial Corridor Needed?." ERIA Policy Brief, No 2009-01, ERIA, Jakarta.

Kumar, N., K. Sevapany, and Y. Chaocheng (eds.) (2008). Asia's New Regionalism and Global Role: agenda for East Asia Summit. New Delhi and Singapore: Research and Information System for Developing Countries.

Menon, J., and T. N. Srinivasan (2018). [Ed]. Integrating South Asia and East Asia, Oxford University 
Press.

Nataraja, G. (2010). India -Japan Investment Relations: Trends and Prospects, ICRIER Working paper No. 245, Indian Council for Research on International Economic Relations, New Delhi.

Noland, M., D. Park, and G. B. Estrada (2013). Developing the service sector as an engine of economic growth: An overview, Manila, Asian development Bank.

Pant, H. (Ed.) (2012). The rise of china: implications for India. New Delhi: Cambridge University Press.

Rana, P. N. B., and M. Dowling (2009). South Asia: Rising to the Challenge of Globalization. Singapore: World Scientific Press.

Reserve Bank of India (2013). India's Exports of Computer Services. RBI Survey. Press Release, New Delhi.

Sankar, U. (2001). "Trade Policy Reforms since 1991: A Review." in Accelerating Growth Through Globalization of Indian Agriculture (pp. 117-132). eds. K.P. Kalirajan, G. Mythili and U. Sankar. New Delhi: Macmillan.

Urata, S. (2008). An economic analysis of competitive regionalism in East Asia, Waseda University, Tokyo. World Bank (2012). East Asian miracle economic growth and public policy, A world bank policy research report, Oxford University Press, New York.

World Economic Forum (2013). Shaping the future of investment. Geneva. 